\title{
The Determinants of the Financing Decision of Listed Companies on the Bucharest Stock Exchange
}

\author{
Vasile ILIE $^{\star}$, Florina-Adriana STĂNICĂ ${ }^{\star \star}$, Nicoleta BĂRBUȚĂ-MIȘU ${ }^{\star \star \star}$
}

\begin{tabular}{l}
\hline \multicolumn{1}{c}{ A R T I C L E I N F O } \\
\hline Article history: \\
Accepted June 2019 \\
Available online July 2019 \\
\hline JEL Classification \\
G32, G30 \\
Keywords: \\
Capital structure theories, Listed \\
companies, Profitability, Growth \\
opportunities, Liquidity, \\
Tangibility
\end{tabular}

\begin{abstract}
A B S T R A C T
The previous literature attempted to provide explanations for the differences identified in the capital structure of companies, with a set of more or less practically applicable theories. This paper aims to capture the influence of the main factors identified in the relevant literature on the capital structure of a sample of listed companies on the main market of the Bucharest Stock Exchange (BVB) and, in particular, to validate or invalidate some of the theories that attempted to explain the differences in the capital structure in the literature. The results show that the capital structure of the Romanian listed companies is positively correlated with the existence of growth opportunities and negatively with the profitability, liquidity, asset tangibility and volatility coefficient.
\end{abstract}

(c) 2019 EAI. All rights reserved.

\section{Introduction}

Financing decisions taken by the companies can influence the availability of funding resources in the future and the procurement costs of these resources. Leveraged firms have associated a higher bankruptcy risk, which leads to an increase in cost of new loans.

Also, investors are more reluctant when deciding on an investment in a more indebted firm because of the priority to pay claims if the firm goes bankrupt, the shareholders being the last persons that recover the invested capital. On the other hand, certain investors regard a high degree of indebtedness as a signal of confidence offered by the creditors of that company.

The degree of debts of a company depends on the stage of the business cycle. Newly established companies need funding to grow. For these, a high volume of debt is expected to increase the value of the business as a result of increasing to the production capacity, volume of services rendered or increasing their quality. Existence of growth opportunities is therefore an issue to be considered when looking at the prospects of an indebted or not indebted company. There are also balance sheet indicators that can provide clues about the prospects of repaying credits or distributing dividends in the future.

\section{Literature review}

The capital structure is the proportion of the use of funding resources available to a company, i.e. the debt to equity ratio. According to the literature on capital structure, the decision to finance companies depends on a series of company-specific factors (e.g. profitability, size, asset structure, growth opportunities) as well as the cost of funding resources, corporate perceptions on the capital market, market conditions, interests of the parties involved in the financing decision, namely shareholders, creditors and managers, the level of taxation, the information asymmetry or the field of activity. Expanding small firms prefer to use internal funding resources to develop new projects at the expense of loans and maintain leverage opportunities through credits for future projects (Fama and French, 2002).

There are many studies on capital structure and its determinants (for example, see: Titman and Wessels, 1988; Shyam-Sunder and Myers, 1999; Fama and French, 2002; Frank and Goyal, 2003; Flannery and Rangan, 2006; Chang and Dasgupta, 2009). In general, authors use almost the same firm characteristics as measures for capital structure. Dependent variables used for the capital structure are expressed both in book and market values. Traditionally, capital structure measures the book leverage, i.e. the ratio of total book debt to total assets (Titman and Wessels, 1988; de Miguel Pindado, 2001; Fama and French, 2002).

The literature sought to explain the differences encountered in the financing of companies by a series of theories. According to capital-structure irrelevance theory, the value of a company does not depend on the 
chosen financing method (Modigliani and Miller, 1958). Trade-off theory shows that companies decide which funding sources will be used mainly on the basis of the cost-benefit relationship of the funding options available (Myers, 2001). Agency theory involves the divergence of interests between the principal and the agent (Jensen and Meckling, 1976). The conflicting interests between the shareholders and the persons mandated to lead the company result from the fact that the management does not benefit from the entire profit obtained as a result of the adoption of new opportunities for the firm or because the eventual loss is borne by the shareholder, management is tempted to submit the firm to higher risks (Harris and Raviv, 1991).

Signal theory implies that a high leverage of a company due to high indebtedness is a positive signal of the company's performance, investors determining the increase of firm value by acquiring the company's shares (Ross, 1977). Pecking order theory (Myers, 1984) highlights that companies prefer to finance mainly by reinvesting profits and then resort to borrowed resources. According to Titman and Wessels (1988), which quote the studies of Myers (1984), Donaldson (1961) and Brealey and Myers (1984), the company's preferred sources of funding are reinvestment of profits, borrowing and new issuance of shares, in this order.

The analysis of Bradley et al. (1984) confirmed the influence of the industry in which a company operates on the structure of its capital. The results also showed that the volatility of profits and the volume of spending allocated to research \& development, and advertising negatively influence the leverage. They also found that tax rates and leverage are evolving in the same way. More recently, Baker and Wurgler (2002) proposed to explain the structure of capital through market timing theory. This theory implies that companies issue shares when the capital market evolve positively and therefore the value of the shares is high, and redeems them when the market value decreases.

Several studies provide evidence that leverage is strongly affected by the company-specific characteristics (Balakrishnan and Fox, 1993). Based on the analysis conducted for the period 1974-1982, for 469 companies, Titman and Wessels (1988) show that companies that develop single products record lower values of indebtedness, and the size of the business is negatively correlated with short-term debt rates. However, the analysis did not identify any influence of the companies' expected growth, tax levels, volatility or asset tangibility on the degree of indebtedness. Considering the period 1987-1991, Rajan and Zingales (1995) found that the leverage of firms in G-7 Member States is positively correlated with asset tangibility and company size, and negatively with profitability and the existence of growth opportunities.

For the case of Romania (the results are summarized in Table 1), the studies performed showed that the leverage is negatively correlated with the profitability (Dragota et al., 2008; Serghiescu and Vaidean, 2014; Brendea, 2014; Sumedrea, 2015; Vatavu, 2015; and Taga and Stanica, 2016b, Nenu et al., 2018), with the tangibility of assets (Dragota et al., 2008; Serghiescu and Vaidean, 2014; Brendea, 2014; Taga and Stanica, 2016a; Taga and Stanica, 2016b - only for the long-term capital structure), the volatility coefficient $\beta$ (Taga and Stanica, 2016b), the level of taxation (Taga and Ilie, 2017), as well as growth opportunities (Dragota et al. and Stanica, 2016b - negative relationship for the book value relative to the market value of the equity) and positively correlated with the firm size (Dragota et al., 2008; Serghiescu and Vaidean, 2014; Brendea, 2014; Sumedrea, 2015; Taga and Stanica, 2016a; Taga and Ilie, 2017; Nenu et al., 2018).

Table 1: Influence of the determinants of the capital structure in the Romanian firms

\begin{tabular}{|c|c|}
\hline Factor & $\begin{array}{l}\text { Correlation } \\
\text { Capital structure } \\
\end{array}$ \\
\hline Profitability & 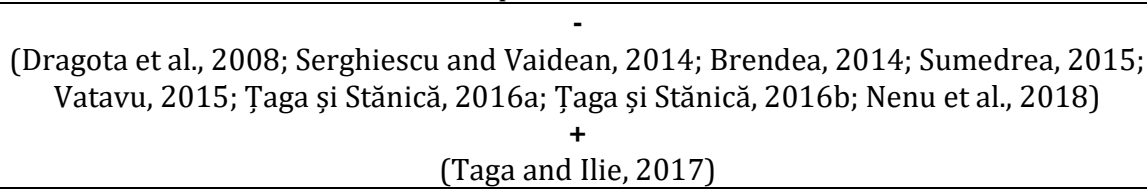 \\
\hline Size & $\begin{array}{c}+ \\
\text { (Dragota et al., 2008; Serghiescu and Vaidean, 2014; Brendea, 2014; Sumedrea, 2015; } \\
\text { Țaga și Stănică, 2016a; Taga and Ilie, 2017; Nenu et al., 2018) }\end{array}$ \\
\hline Tangibility & $\begin{array}{l}\text { (Dragota et al., 2008; Serghiescu and Vaidean, 2014; Brendea, 2014, Țaga și Stănică, } \\
\text { 2016a) }\end{array}$ \\
\hline $\begin{array}{l}\text { Market value / Book value of } \\
\text { equity }\end{array}$ & $\begin{array}{c}+ \\
\text { (Brendea, 2014; Țaga și Stănică, 2016b) } \\
\end{array}$ \\
\hline Volatility of shares & $\begin{array}{c}- \\
\text { (Țaga și Stănică, 2016b) } \\
+ \\
\text { (Nenu et al., 2018) }\end{array}$ \\
\hline Taxation & $\begin{array}{c}- \\
\begin{array}{c}\text { (Taga and Ilie, 2017) } \\
+ \\
(\text { Nenu et al., 2018) }\end{array}\end{array}$ \\
\hline Liquidity & - \\
\hline
\end{tabular}


(Serghiescu and Vaidean, 2014; Nenu et al., 2018)

Total assets turnover

(Serghiescu and Vaidean, 2014)

Growth opportunities

(Dragota et al., 2008; Brendea, 2014; Nenu et al., 2018)

Source: Performed by the authors

Using as profitability indicator the ratio between the value of the EBIT and the total value of the assets, Taga and Ilie (2017) identify a positive relationship between the total and long-term leverage and profitability, contrary to the pecking order theory of Myers (1984). Dragota et al. (2008) analyse the companies' funding policies and validates the existence of the industry effect for listed companies in Romania using data for the period 1997-2005. The results of the study confirm the effects of tangibility, profitability, size and growth opportunities on the capital structure. Based on the analysis for 20 companies listed on the BVB covering the period 2009-2011, Serghiescu and Vaidean (2014) conclude that the structure of a company's capital is negatively influenced by the profitability, liquidity and asset tangibility and positive by the size of the company and the rotation of the total asset.

Based on the analysis of the balance sheet information for a sample of 77 companies for the period 2004-2011, Brendea (2014) shows that corporate indebtedness increases as the size of the business increases and the result of the ratio between market value and the book value of equity capital. Also, the results have shown that the indebtedness of firms is negatively correlated with profitability, growth opportunities and asset tangibility. Vatavu (2015) analysed, for the period 2003-2010, the relationship between the capital structure and the financial performance for 196 companies operating in the manufacturing sector listed on the Bucharest Stock Exchange. The empirical results showed that during the analysed period, the most profitable companies were those with a low level of debt to equity ratio.

Sumedrea (2015) analysed the factors that contributed to overcoming the effects of the 2008-2011 financial crisis on a sample of 66 Romanian companies, identifying a pattern of the capital structure that allowed them to continue the activity and sustainable development. According to the results obtained by Sumedrea (2015), the degree of debts of the companies during the analysed period is negatively influenced by the return on equity and positive by the firm size.

Taga and Ilie (2017) analysed the relationship between capital structure and profitability expressed by the ratio between EBIT and total assets. In addition, in the analysis were considered: the company's size determined as the logarithm of the turnover, tax influence approximated by the logarithm of the total amount of taxes paid by the company in a given tax year, as well as the ratio between the market value and the book value of the equity capital on the last day of the year.

Over the period 2000-2016, Nenu et al. (2018) confirms that there is a positive correlation between leverage and (i) firm size and (ii) the volatility coefficient related to shares and negative between profitability and leverage. As Titman and Wessel (1988) emphasize, the studies that seek to identify and analyse the factors that determine the capital structure of a company use different approximations for the same determinant factor, which may determine obtaining contrary results. Also, Rajan and Zingales (1995) pointed out the need to identify more accurate approximations of the factors that influence the structure of capital.

Capital structure may also be influenced by macroeconomic factors. One factor that influences the financing decisions is the degree of development and evolution of the capital market. The more liquid the capital market, the lower the transaction costs, and so there are more investors willing to finance the business, increasing the attractiveness of equity financing. In fact, according to the market timing theory, companies issue shares when the capital market evolves positively and redeems them when the market is down.

Due to the tax savings of companies that are financed by loans, it is expected that the debt / equity ratio to increase over periods when fiscal policy is more restrictive. Mokhova and Zinecker (2014) analysed the influence of macroeconomic factors in the EU manufacturing sector (Czech Republic, France, Germany, Greece, Poland, Slovakia and Hungary) in 2006-2011. The authors demonstrated the influence of the macroeconomic conditions on the financing decision of the companies from two perspectives: the impact of the monetary and fiscal policy.

\section{Data and methodology}

\subsection{Data description}

The data were taken from listed companies on the main market of the Bucharest Stock Exchange (BVB), where are listed companies organized as joint stock companies with an equity value or anticipated stock market capitalization of at least EUR 1 million, a factor of free-float of at least $25 \%$ and who have prepared and reported the financial statements for at least the last 3 years.

On March 30, 2018, 87 companies were listed on the BVB's main market, in the Int'l category - 3 companies, Premium - 24 companies and Standard - 60 companies (Figure 1). The study was conducted on the basis of publicly available information on the financial statements of the companies included in the list of 
companies listed on that date, collected from the BVB website - the Financial Information section, for each issuer, the reference period being considered 2007-2017. The financial statements of listed companies within the analysed period were taken into account, and data was collected for the pre-listing period, wherever possible.

Figure 1: Evolution of the number of companies listed on the BSE during the period 2007 - Q1 2018

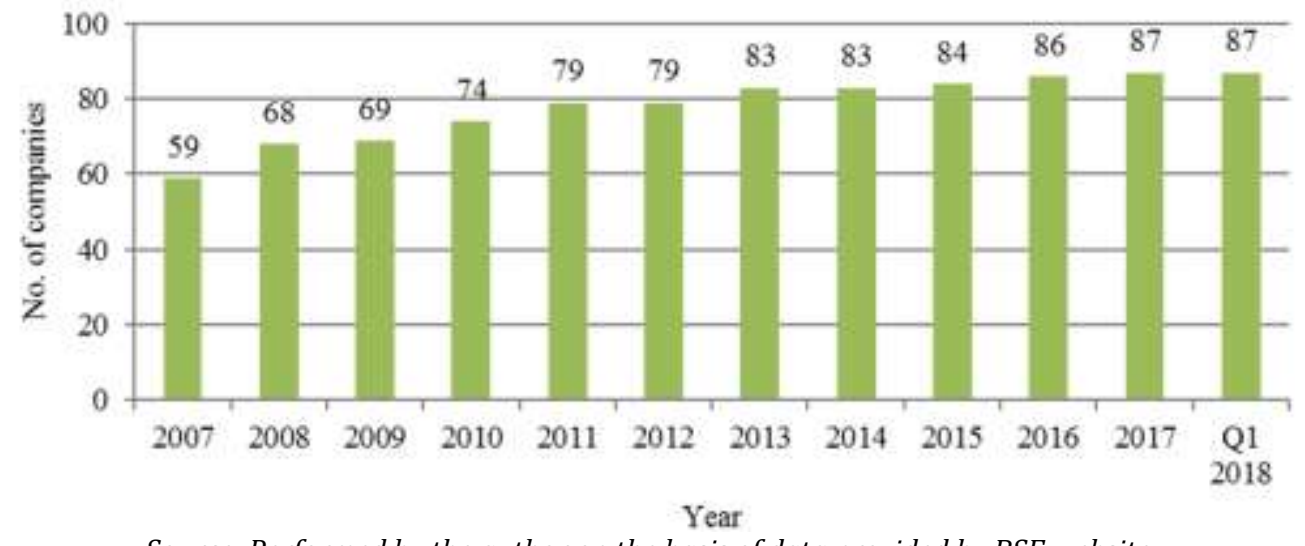

Source: Performed by the author on the basis of data provided by BSE website

According to Figure 1, there is an upward trend in the number of companies listed on the BVB, which is approximately $47 \%$ higher at the end of the first quarter of 2018 compared to the one recorded in the beginning of the period considered for analysis, respectively the year 2007. Also, during the analysed period, total market capitalization has increased since 2009, with a decrease in 2011 (Figure 2). The financial crisis of 2008 has also been manifested by the drastic decline in stock market capitalization and the return on the benchmark of the Romanian capital market - the BET index.

Figure 2 illustrates also the evolution of the BET-NG index - the index for the companies active in the field of energy, which follows the same trend as the main index of the Romanian capital market, the difference being represented by the magnitude of evolution. Thus, it can be noticed that in 2008 the annual BET-NG index declined more than the BET index. Of the companies studied, the companies traded in the Int'l category were excluded, as there is insufficient information available on the BVB website to carry out a rigorous analysis.

Figure 2. The evolution of the Romanian capital market during the period 2007-2017

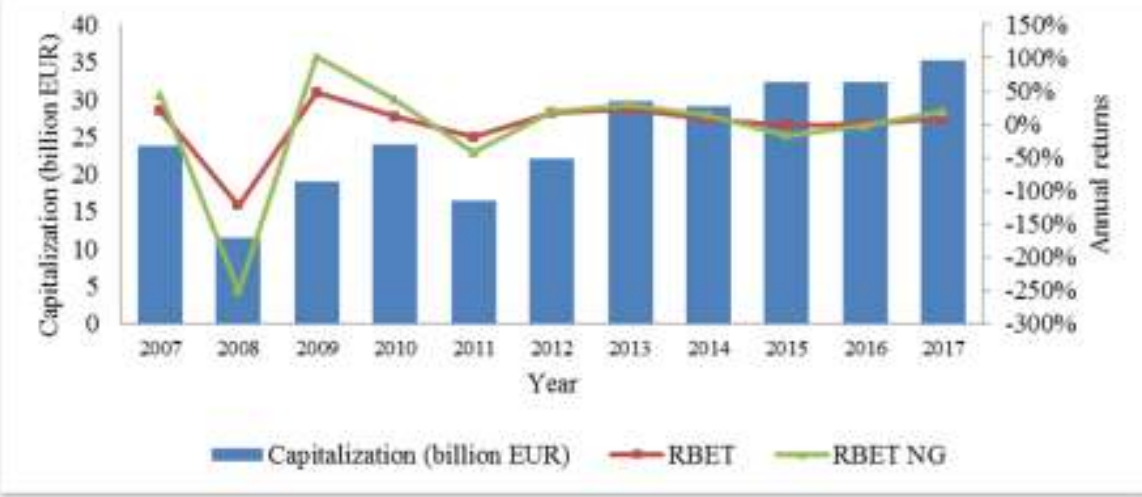

Source: Performed by the author on the basis of data provided by BSE website

The companies that are in the sample after the above mentioned adjustment (84 companies) operate in various sectors of activity, most of the listed companies on the BVB belong to the manufacturing sector $(52.38 \%)$, followed by the financial intermediation sector and insurance $(15.48 \%)$. Most companies listed on the BVB's main market are established in Bucharest and Ilfov County (27.38\%), with about 64\% more companies than in the second development region, according to the number of listed companies set up, North -Vest and only two companies come from the West Development Region.

The classification of the National Institute of Statistics (NIS) and the information available on the BVB website regarding the county where the companies in the sample are located are used for the classification of companies by development regions. 
Of the 84 companies registered in Romania that were trading on the main market of the BVB in Standard and Premium categories, on March 30, 2018, the 13 companies are active in financial intermediation and insurance, being removed from the sample.

Figure 3. Distribution of companies listed on BVB by region of development (March 30, 2018)

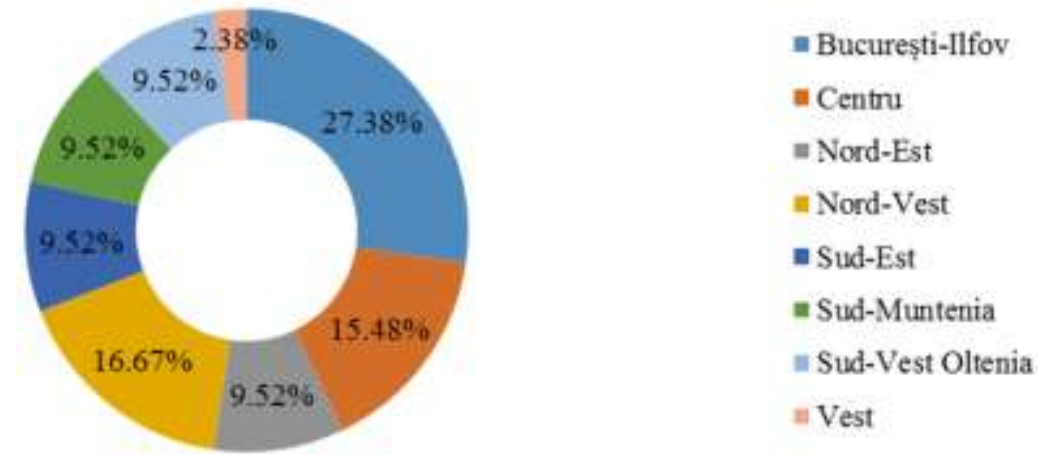

Source: Performed by the author on the basis of data provided by BSE and INS website

The reasons for removing the financial sector companies from the sample offer us Rajan and Zingales (1995): their leverage is strongly influenced by explicit (or implicit) investor insurance schemes such as deposit insurance, their debt-like liabilities are not strictly comparable to the debt issued by nonfinancial firms, regulations such as minimum capital requirements may directly affect capital structure (Rajan and Zingales, 1995)

Figure 4. Evolution of the number of companies with negative equity or net result

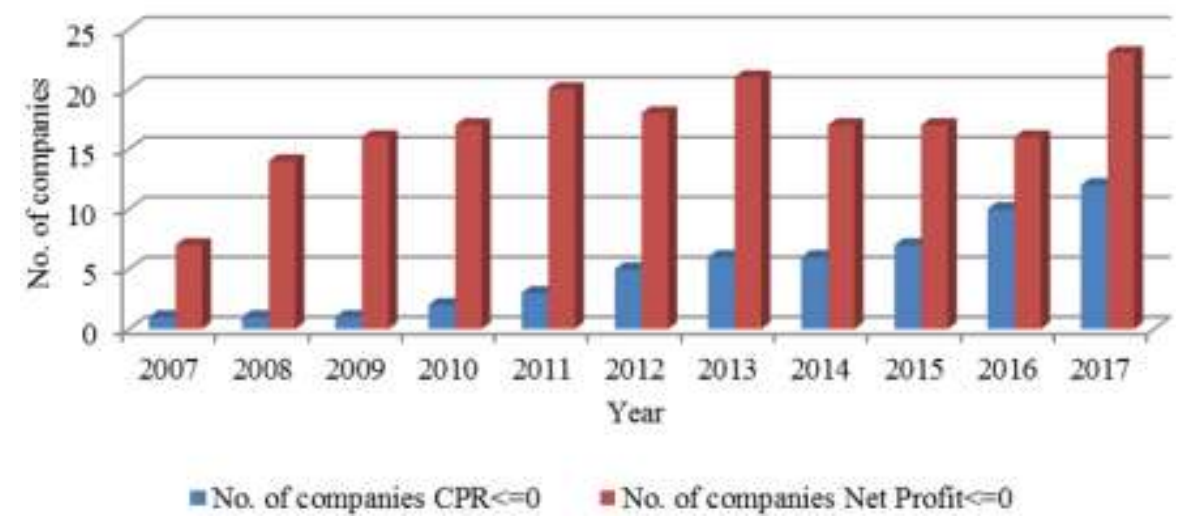

Source: Performed by the author on the basis of data available in Financial statements of the companies studied

In addition, the observations of the years when companies registered negative equity capital were removed from the sample. The evolution of the number of companies for which negative values of equity capital and net result were recorded is illustrated in Figure 4.

It can be noticed that the number of companies that registered negative equity capital during 20072017 has been increasing, evolving from 1 company between 2007 and 2009, when the effects of the financial crisis were felt at 10 in the period 2016-2017. In terms of net result, the largest number of companies with a negative value was reached for the analysed period in 2013 and 2017 (21 companies).

Although the aggregate value of turnover (TOv) for the entire sample, relative to the gross domestic product (GDP) illustrated in Figure 5, was between 5.6\% and 9.7\% in the period 2007-2017, we cannot consider the sample as a representative one for the situation of a Romanian company. A possible deficiency in the analysis may be the construction of the sample exclusively from large companies, which represent only a small part of the companies operating in a state (Rajan and Zingales, 1995). 
Figure 5. The evolution of TOv/GDP and the average number of employees (aggregated annual values of the sample)

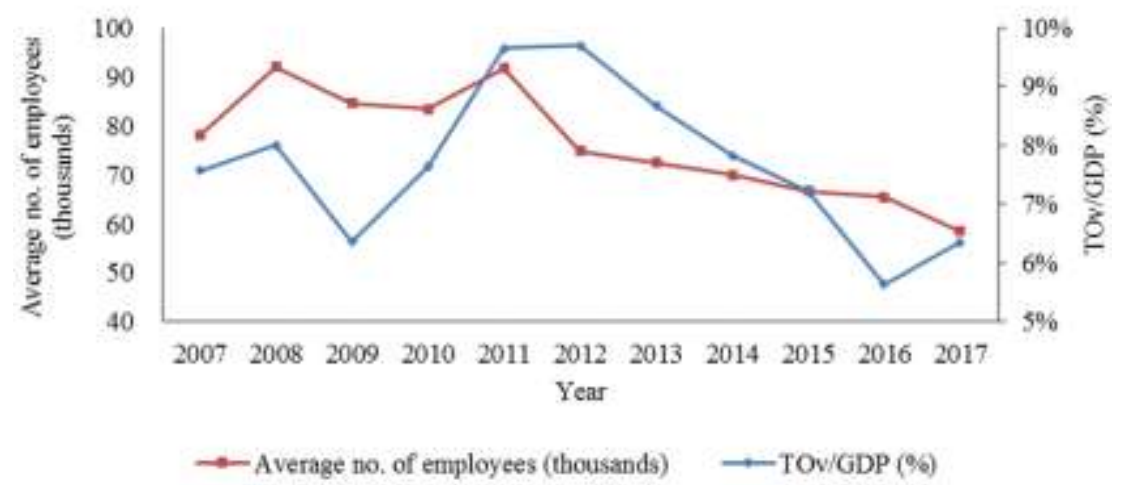

Source: Performed by the author based on data provided in the Monthly Bulletins of the National Bank of Romania for the period 2008-2018 and of data available in Financial statements of the companies included in the sample

Also, it can be seen from Figure 6 that the number of companies in the sample that distributed or announced that they will distribute dividends has increased significantly from 2011 . Thus, the average number of companies that granted dividends was 19 in 2007-2011 and 29 in the period 2012-2017. We mention that the results for 2017 are not final, only companies that have made public the decision on the distribution of dividends by 1 May 2018 are included.

Figure 6. Evolution of the number of companies that distributed / announced they wanted to distribute dividends over the 2007-2017 period

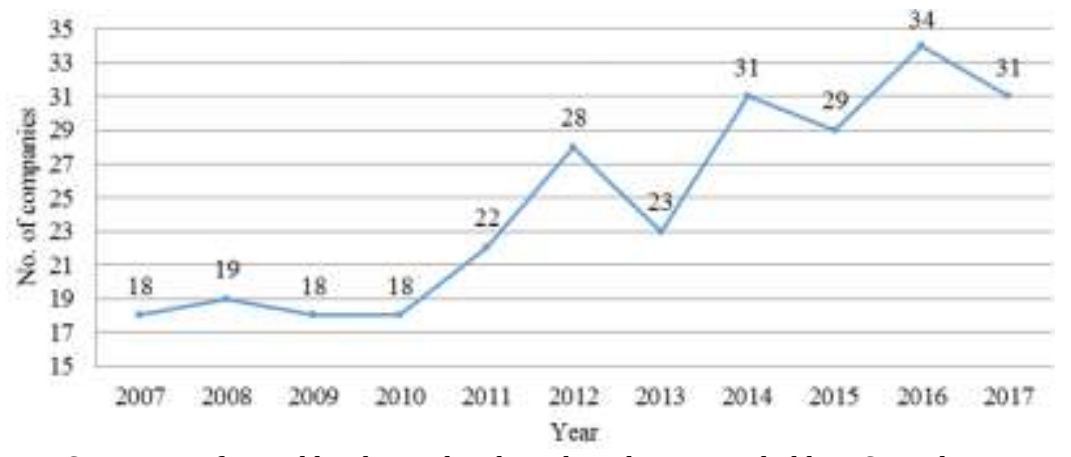

Source: Performed by the author based on data provided by BSE website

\subsection{Model variables and methodology}

In order to analyse the factors influencing the capital structure and, implicitly, the financing decision of the listed companies on the BVB's main market, it started from the 87 companies that were trading on March 30, 2018, eliminating those companies that are not registered in Romania, companies traded in the Int'l category and companies belonging to the financial intermediation and insurance sector, reaching the sample of the 71 companies.

Adjustments were made to eliminate, for each company where applicable, those years in which negative amounts of equity capital were recorded and the years for which all the variables required for the study could not be determined. After making these adjustments, 65 companies (522 annual observations) were included in the final sample used for the analysis.

The aim of this study is to capture the influence on the capital structure of the main factors identified in the literature for the companies that were traded on the main market of the BVB on March 30, 2018.

\section{Capital structure}

In the literature, the capital structure is approximated by many indicators, such as the ratio of the value of debts (total or matched by maturity) and (i) the total book value of assets (Brendea, 2014; Serghiescu and Vaidean, 2014; Sumedrea, 2015; Vatavu, 2015; Nenu et al., 2018) or (ii) the book market value of the equity capital (Titman and Wessels, 1988; Rajan and Zingales, 1995; Dragota et al., 2008; Taga si Ilie, 2017), as well as the ratio between equity capital and total assets (Vatavu, 2015).

In order to highlight the factors influencing the financing decision of listed companies on the BVB main market, the capital structure of a company $i$, related to the year of activity $t$, was approximated by the total leverage rate, determined according to equation (1): 


$$
\text { Leverage }_{i t}=\frac{\text { Debts }_{\text {it }}(\mathrm{c})}{\text { Equity }_{\text {it }(\mathrm{c})}}
$$

where:

Debts $_{i t(c)}=$ the book value of the total debts of the company $i$ in year $t$;

Equity $_{\text {it(c) }}=$ the book value of the equity capital of the company $i$ in year $t$.

The determination of this indicator was made only for the years in which the book value of the equity capital has registered positive values.

Based on the conclusions of the literature analysis, the following factors were used for studying the influence on the financing decision of the companies: profitability, firm size, asset tangibility, liquidity, growth opportunities, volatility coefficient of the share and belonging to a particular sector of activity.

\section{Firm profitability}

Some of the studied articles analyze the relationship between the cost of equity and the profitability of a company through (i) Return on Equity (ROE), determined as a ratio between net profit and equity capital (Sumedrea, 2015; Vatavu, 2015), or (ii) Return on Assets (ROA), determined as the ratio between the net profit and the total value of the assets (Brendea, 2014; Vatavu, 2015; Nenu et al., 2018).

In other studies, the authors approximate the profitability as the ratio of EBIT to the total value of the assets (Dragota et al., 2008; Serghiescu and Vaidean, 2014; Taga and Ilie, 2017) or the total value of equity (Taga and Ilie, 2017). The EBIT value is determined as the sum of the current result before tax and the interest and similar expense (Vintila, 2006).

Titman and Wessels (1988) approximate profitability by two indicators, (i) the ratio of operating income and the value of sales, and (ii) the ratio of operating income to total assets. Rajan and Zingales (1995) approximate profitability with the ratio of EBITDA to book value of asset.

Given the options offered by the literature, it was considered that the use of operating income rather than net profit as the basis of determining the company's profitability may be a better measure to delineate the effects of company financing decisions. Also, in the case of an indebted company, but which manages to use efficiently the resources in the operational activity, the profit diminished by the interest expenses may not reflect the real prospects of the company.

As such, it is expected that the capital structure of a company to be influenced by the firm's ability to use resources to generate operating income, of which thereafter, interest, taxes and other fees due will be paid. Therefore, the indicator used to approximate profitability is described in Equation (2):

$$
\text { Profitability }_{\text {it }}=\frac{\text { Netincome }_{\text {it }}}{\text { Total Assets }_{\text {it(c) }}}
$$

where:

Net income $_{\text {it }}=$ the operating income of the company $i$ in year $t$;

Total Assets $_{\mathrm{it}(\mathrm{c})}=$ the book value of total assets of the company $i$ in year $t$.

\section{Firm size}

Larger companies are more transparent to investors. Thus, the problems of information asymmetry are less severe. These companies have a higher preference for external financing and are able to obtain more bank credit, whereas smaller companies use frequently internal financing (De Haas and Peeters, 2006). Thus, larger companies tend to operate on more leverage, because they are more transparent, have lower asset volatility, or have better access to public debt markets (Flannery and Rangan, 2006). This is in line with trade-off theory (Jensen and Meckling, 1976; Mao, 2003; Antoniou et al., 2008; De Jong et al., 2008), since larger companies tend to be associated with lower financial distress costs and use more leverage.

To approximate the size of the firm, we used the indicator proposed by Titman and Wessels (1988) and Rajan and Zingales (1995), respectively the net turnover logarithm, according to the equation (3).

$$
\text { Size }_{\text {it }}=\ln \left(\mathrm{TOv}_{\mathrm{it}(\mathrm{c})}\right)
$$

where:

$\mathrm{TOv}_{\text {it }(\mathrm{c})}=$ net turnover registered by company $i$ in year $t$.

This indicator has also been identified in studies conducted for Romanian companies by Dragota et al. (2008), Brendea (2014), Sumedrea (2015) and Taga and Ilie (2017). 
Other methods of approximating the firm size identified in the literature are the logarithm calculated for the book value of the total assets (Titman and Wessels, 1988, Serghiescu and Vaidean, 2014, Nenu et al., 2018) or the natural logarithm of the market capitalization value (Dhaliwal et al., 2007).

\section{Assets tangibility}

This indicator was determined according to equation (4) and represents the weight of fixed assets in total book value of assets. Since fixed assets can be used as collateral for loans, companies that record high values of this indicator should contract more easily bank loans. In this situation, it is expected that the leverage and asset tangibility indicator will evolve positively, debts having a higher share in the capital structure for companies that record high values of the fixed assets.

$$
\text { Tangibility }_{\text {it }}=\frac{\text { Fixed Assets }_{\text {it(c) }}}{\text { Total Assets }_{\text {it(c) }}}
$$

where:

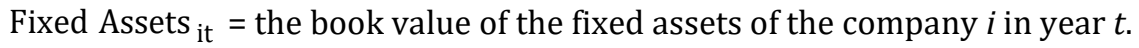

For this indicator the literature seems to have reached a consensus, this approximation being found in most of the analysed studies.

\section{Liquidity}

In the relevant literature on capital structure, liquidity is approximated (i) as the ratio between cash and cash equivalents and total value of assets (Serghiescu and Vaidean, 2014), (ii) current liquidity (Vatavu, 2015; Nenu et al., 2018) or (iii) the ratio between cash and cash equivalents plus current receivables and short-term liabilities (Nenu et al., 2018).

For this analysis the current liquidity was used, calculated according to equation (5):

$$
\text { Liquidity }_{\text {it }}=\frac{\text { Current Assets }_{\text {it(c) }}}{\text { Current Liabilities }_{\text {ic(c) }}}
$$

where:

Current Assets ${ }_{\text {it(c) }}=$ the book value of total current assets of the company $i$ in year $t$;

Current Liabilities $_{\text {it(c) }}=$ the book value of current liabilities (payable over a period of one year) of the firm $i$ in year $t$.

The value of current liquidity shows the ability of a company to meet its short-term payment obligations to current assets. The higher the current assets than the current debt of a company, the better it can meet its payment obligations. A value less than 1 shows that short-term debt funds a part of long-term assets.

\section{Growth opportunities of a company}

To highlight growth opportunities, the approximation proposed by Myers (1977) and subsequently used in other studies (Titman and Wessel, 1988; Rajan and Zingales, 1995), respectively the ratio between market value and book value of the company's assets, according to equation (6) may be used:

$$
\text { Growth opportunities }=\frac{\text { Market Total Assets }_{\text {it }(p)}}{\text { Book Total Assets } \text { it(c) }_{\text {Tol }}}
$$

where:

Book Total Assets $_{\text {it(p) }}=$ the market value of total assets of the company $i$ in year $t$.

Since we did not have information on the market value of assets, we adapted the above formula according to Dragota et al. (2008), and we used the ratio of (i) the sum of the total book value of debt and market capitalization and (ii) the sum of the book value of total debt and equity.

$$
\text { Growth Opportunities }=\frac{\text { Debts }_{\text {it }(c)}+\text { Market capitalization }_{\text {it }(p)}}{\operatorname{Debts}_{\text {it }(c)}+\text { Equity }_{\text {it(c) }}}
$$

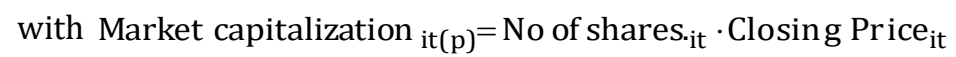

where:

Market capitalization $_{\mathrm{it}(\mathrm{p})}=$ the market value of the equity of the company $i$ in year $t$;

No of shares $_{\text {it }}=$ the total number of shares of the company at the end of year $t$; 
Closing Price $_{\text {it }}=$ the daily closing price of the company's shares in the last day of December of the year $t$ in which it was traded.

Another indicator used to capture growth opportunities is the percentage change in net turnover (Brendea, 2014; Sumedrea, 2015; Nenu et al., 2018).

The stock's volatility coefficient of a company (volatility coefficient $\beta$ )

The formula for calculating the volatility coefficient associated with a company's share is illustrated in Equation (9).

$$
\beta_{\mathrm{it}}=\frac{\operatorname{cov}\left(\mathrm{R}_{\mathrm{it}}, \mathrm{R}_{\mathrm{Mt}}\right)}{\operatorname{var}\left(\mathrm{R}_{\mathrm{Mt}}\right)}
$$

where:

$\mathrm{R}_{\mathrm{it}}=$ the monthly stock's return of the company $i$ in the 3 years prior to year $t$;

$\mathrm{R}_{\mathrm{Mt}}=$ profitability of the market portfolio.

In order to be comparable to the companies in the sample, considering that the value of the leverage differs, we have used in this analysis for this indicator the value of the volatility coefficient for an unlevered firm, the value resulted according to equation (10) being adjusted by taking into account the leverage and the tax rate (Obreja Brasoveanu et al., 2008):

$$
\beta_{\mathrm{Uit}}=\frac{\beta_{\mathrm{it}}}{1+\left(1-\tau_{\mathrm{t}}\right) * \mathrm{LEV}_{\mathrm{it}}}
$$

where:

$\tau_{\mathrm{t}}=$ tax rate in year $t$.

\section{Estimation of the econometric model}

The empirical estimation of the model that captures the influence of the indicators considered on the capital structure was achieved using the Eviews 8 application, a model with unbalanced panel data being estimated.

The panel data model has the following equation (11):

with $\mathrm{i}=1, \ldots, \mathrm{N} ; \mathrm{t}=1, . . \mathrm{T}$;

$$
y_{i t}=\alpha+X_{i t} \times \beta+\mu_{i}+\varepsilon_{i t}
$$

where:

$\mathrm{i}=$ cross-sectional dimension;

$\mathrm{t}=$ period;

$\alpha, \beta=$ the coefficients of the equation;

$\mathrm{X}_{\mathrm{it}}=$ observation $i$ of explanatory variables;

$\mu_{\text {it }}=$ individual unobservable specific effects;

$\varepsilon_{\text {it }}=$ the residual term.

The explained / dependent variable was considered the capital structure, approximated by the leverage ratio, respectively the ratio between book value of total debts and book value of the equity, and as explanatory / independent variables the profitability, current liquidity, firm size, growth opportunities, the volatility of the companies from which the leverage effect was eliminated and asset tangibility.

\section{Results}

Figure 7 shows the evolution of the median values of the four profitability indicators used in the literature, namely ROE, ROA, the ratio of operating income and total value of the assets (EBIT/TA), as well as the ratio of the operating income to the net turnover (EBIT/TOv). Of the four indicators, two refer to net income (ROE and ROA) and registered the same evolution. The other two indicators that rely on the operating income had a steeper evolution, the highest profitability being recorded by the EBIT/TOv ratio.

In order to identify the factors influencing the capital structure in the case of the companies listed on the BVB main market, we used EBIT/TA ratio, which recorded values between ROE and ROA. 
Figure 7. Different ways to measure profitability (median values)

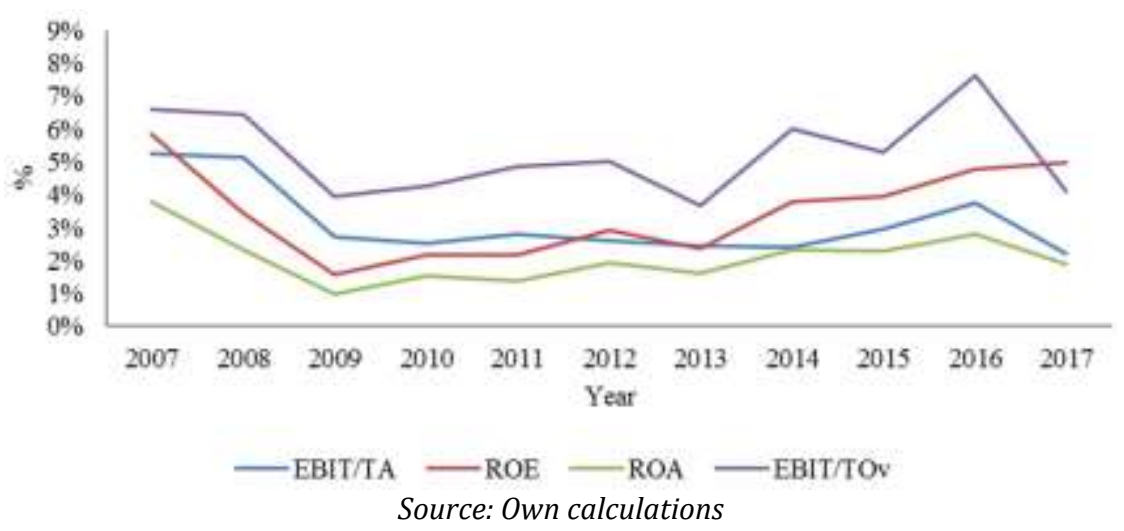

Figure 8 shows graphically the most tested factors of the literature. According to the graphical representation, the relationship between current liquidity and leverage is negative. The evolution of the company's average size and asset tangibility follows the same pattern and, they have roughly the same trend as the ratio debt to equity.

Figure 8. Descriptive analysis of the main factors determining the financing decision of the company (median values)

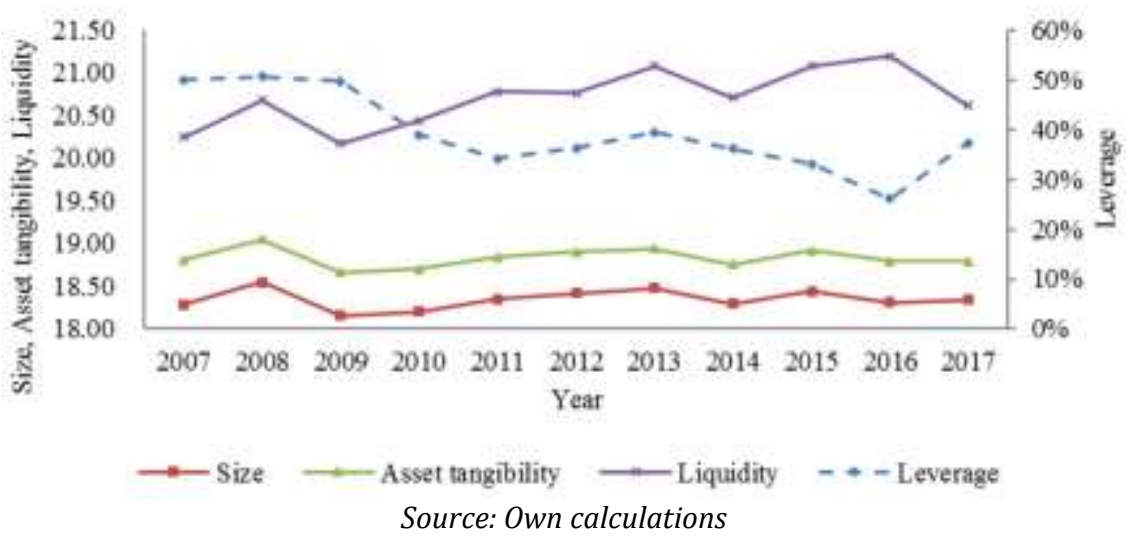

Table 2 illustrates the descriptive statistics of data series. The median leverage value (0.38) indicates that in the period 2007-2017 the value of debts was lower than the value of equity, which indicates that companies preferred equity financing or self-financing, the value of equity being higher by 2.63 times than the amount of debts. On the other hand, on average, companies have used approximately equal proportion of debts and equity in their financing.

Regarding profitability, according to the median value, during the period 2007-2017 the companies achieved an operating income of approximately $3 \%$ of the total value of the assets. The value of the current liquidity was approximately 1.87 (median value), indicating that the firms in the sample performed well in terms of their ability to meet short-term payment obligations to current assets.

Also, the existence of a high value of current assets is also evidenced by the value of asset tangibility. The tangibility indicator has a value of approximately 0.5 on both values of average and median, indicating that the value of tangible fixed assets was approximately equal to current assets.

Table 2. Descriptive statistics

\begin{tabular}{ccccccccc}
\hline & Leverage & Profitability & Size & Liquidity & Growth & $\beta_{\mathrm{U}}$ & Tangibility \\
\hline Mean & 0.96 & 0.04 & 18.52 & 3.42 & 0.80 & 0.43 & 0.51 \\
Median & 0.38 & 0.03 & 18.40 & 1.87 & 0.73 & 0.40 & 0.47 \\
Maximum value & 31.68 & 0.24 & 23.69 & 39.95 & 3.86 & 1.80 & 2.07 \\
Minimum value & 0.01 & -0.26 & 13.29 & 0.20 & 0.01 & -0.47 & 0.02 \\
Skewness & 8.27 & -0.34 & 0.60 & 3.99 & 2.33 & 0.62 & 0.66 \\
Kurtosis & 95.74 & 5.22 & 3.75 & 23.35 & 12.06 & 3.79 & 5.44
\end{tabular}




\begin{tabular}{cccccccc}
\hline & Leverage & Profitability & Size & Liquidity & Growth & $\beta_{\mathrm{U}}$ & Tangibility \\
\hline Jarque-Bera & 189698.30 & 114.66 & 42.73 & 10215.59 & 2220.47 & 46.04 & 165.28 \\
Prob. & 0.0000 & 0.0000 & 0.0000 & 0.0000 & 0.0000 & 0.0000 & 0.0000 \\
No. obs. & 513 & 513 & 513 & 513 & 513 & 513 & 513 \\
\hline \multicolumn{7}{c}{ Source: Own calculations }
\end{tabular}

The value of the volatility coefficient $\beta$ indicates that, on average, sampled companies are less risky than market portfolio, represented by the BET index $(\beta<1)$.

The ratio of the market value and the book value of debts and equity capital is 0.8 on average. This result shows that, on average, firms in the sample are not perceived as having growth prospects in the future. However, there are also companies in the sample for which the value of this ratio is higher than 0.8; maximum is around 3.9, which provide optimistic prospects of potential investors / creditors.

The annual variables are not normally distributed (the probability associated with the Jarque-Bera test is less than 5\%), being leptokurtosis (kurtosis> 3) and asymmetric to the right - there are several companies with values lower than the average (except for the profitability series, with the value of the skewness indicator $<0$ ).

Before estimating the regression model according to equation (11), the matrix of correlation between independent variables and lever was generated. The results are presented in Table 3.

Table 3. Correlation Matrix

\begin{tabular}{lccccccc}
\hline & Leverage & Profitability & Size & Liquidity & Growth & $\beta_{\mathrm{U}}$ & Tangibility \\
\hline Leverage & 1 & -0.21 & 0.12 & -0.20 & 0.11 & -0.22 & -0.03 \\
Profitability & -0.21 & 1 & 0.34 & 0.00 & 0.40 & 0.06 & -0.19 \\
Size & 0.12 & 0.34 & 1 & -0.26 & 0.35 & 0.09 & -0.18 \\
Liquidity & -0.20 & 0.00 & -0.26 & 1 & -0.10 & 0.11 & -0.14 \\
Growth & 0.11 & 0.40 & 0.35 & -0.10 & 1 & 0.04 & -0.34 \\
$\beta_{U}$ & -0.22 & 0.06 & 0.09 & 0.11 & 0.04 & 1 & -0.01 \\
Tangibility & -0.03 & -0.19 & -0.18 & -0.14 & -0.34 & -0.01 & 1 \\
\hline \multicolumn{7}{c}{ Source: Own calculations } \\
\hline
\end{tabular}

The highest values of the correlation coefficient of leverage were recorded for volatility coefficient, profitability and liquidity. However, correlation coefficient values are not high, which allows estimation of the model using the determinants described in the methodology section.

According to the correlation matrix, profitability, liquidity, volatility and asset tangibility are negatively correlated with leverage, while size and growth opportunities have a positive impact on the leverage.

Also, the data series stationarity has been verified. To check the integration order for the series, the information provided by Eviews 8 was used in the summary of the results obtained by applying the stationary tests for panel data models.

The conclusions drawn by using Eviews 8 are based on the results obtained applying four stationary tests: (i) Levin, Lin and Chu, (ii) Im, Pesaran and Shin, (iii) Fisher - ADF and (iv) Fisher - PP. All four tests have as a null hypothesis that there is a root unit, respectively the series analysed is not stationary. If the probability associated with stationary tests records values greater than 0.05 , then the null hypothesis cannot be rejected, and the series are non-stationary. For its stationarity, the first or second difference obtained by successive logarithms is used.

In this analysis, the series of variables that quantify profitability, size, growth opportunities and assets tangibility were used in the regression model estimated in logarithm form (the $1^{\text {st }}$ order difference) to address the problem of non-stationarity. The results of the stationary test of all the series analysed in this chapter are presented in Table 4.

Table 4. Tests of stationarity

\begin{tabular}{ccccc}
\hline & & Stationarity test & & \\
Variable & Levin, Lin and Chu & Im, Pesaran and Shin & Fisher ADF & Fisher PP \\
\hline Leverage & $-14.09^{* * *}$ & $-2.53^{* * *}$ & $169.08^{* * *}$ & $187.85^{* * *}$ \\
Profitability & 1.76 & $-4.34^{* * *}$ & $201.11^{* * *}$ & $235.27^{* * *}$ \\
d(Profitability) & $-25.49^{* * *}$ & $-12.60^{* * *}$ & $336.67^{* * *}$ & $465.13^{* * *}$ \\
Size & $-5.72^{* * *}$ & -0.53 & 116.63 & 118.03
\end{tabular}




\begin{tabular}{ccccc} 
d(Size) & $-21.67^{* * *}$ & $-9.54^{* * *}$ & $279.58^{* * *}$ & $311.06^{* * *}$ \\
Liquidity & $-100.71^{* * *}$ & $-10.59^{* * *}$ & $172.32^{* * *}$ & $205.59^{* * *}$ \\
Growth & 1.42 & $-15.68^{* * *}$ & $404.27^{* * *}$ & $469.94^{* * *}$ \\
d(Growth) & $-53.85^{* * *}$ & $-25.33^{* * *}$ & $527.61^{* * *}$ & $653.83^{* * *}$ \\
Volatility coefficient $\beta_{\mathbf{U}}$ & $-11.78^{* * *}$ & $-4.16^{* * *}$ & $179.30^{* * *}$ & $173.94^{* * *}$ \\
Tangibility & $-9.67^{* * *}$ & -0.64 & 120.08 & $144.00^{* *}$ \\
d(Tangibility) & $-22.38^{* * *}$ & $-11.69^{* * *}$ & $323.75^{* * *}$ & $408.39^{* * *}$ \\
\hline
\end{tabular}

Source: Own calculation using Eviews 8, based on data provided by BVB, NBR, KTD Invest S.A., Interfinbrok Corporation S.A. website; $^{* * *},{ }^{* *}=$ significance level of $1 \%$, respectively $5 \%$

After checking the stationarity of the data series or solving this problem where appropriates, a regression model was estimated to highlight the possible influences of the explanatory variables considered on the capital structure. The econometric analysis was carried out with a panel model using the Pooled OLS method. The estimated model included all factors considered in the methodology, being considered as independent variables profitability, liquidity, size, growth opportunities, volatility coefficient of the unlevered firm and the asset tangibility.

The estimated equation is:

$$
\begin{aligned}
& \text { Leverage }_{t}=\beta_{1 \mathrm{t}} \cdot \text { Profitability }+\beta_{2 \mathrm{t}} \cdot \text { Size }+\beta_{3 \mathrm{t}} \cdot \text { Liquidity }+\beta_{4 \mathrm{t}} \cdot \text { Growth }+ \\
& +\beta_{5 \mathrm{t}} \cdot \text { BetaU }+\beta_{6 \mathrm{t}} \cdot \text { Tangibility }+\varepsilon_{\mathrm{t}}
\end{aligned}
$$

The results obtained for estimating the regression model in equation (12) can be found in Table 5. All coefficients of the variables in the final model are statistically significant.

Regarding the relationship between profitability and leverage, the econometric analysis revealed that the ratio debt to equity is negatively influenced by the ratio between the operating income and total value of the assets. This means that the more profitable a company is, the more debt-to-equity ratio is decreasing. This result confirms the pecking order theory, according to which companies prefer primarily financing by reinvesting profits (Myers, 1984; Titman and Wessels, 1988).

According to Figure 8, liquidity inversely influences the capital structure. Therefore, firms with better short-term liquidity, respectively firms for which the value of the ratio between current assets and current liabilities increases, are less indebted and rely more on funding from internal resources or resources attracted from shareholders.

Table 5. The results of the regression model estimation

\begin{tabular}{ccc}
\hline Variable & Coefficient & t-Statistic \\
\hline LOG(Profitability) & $-0.19^{* * *}$ & -3.34 \\
LOG(Size) & $0.16^{* *}$ & 1.98 \\
Liquidity & $-0.06^{* * *}$ & -4.92 \\
LOG(Growth) & $0.33^{* * *}$ & 3.29 \\
BetaU & $-0.73^{* * *}$ & -4.55 \\
LOG(Tangibility) & $-0.39^{* * *}$ & -3.50 \\
\hline R-squared & \multicolumn{2}{c}{0.18} \\
Durbin-Watson stat & \multicolumn{2}{c}{0.60} \\
N (total observation panel unbalanced) & \multicolumn{2}{c}{417} \\
\hline
\end{tabular}

Source: Own calculation using Eviews 8, based on data provided by BVB, NBR, KTD Invest S.A., Interfinbrok Corporation S.A. website ${ }^{* * *},{ }^{* *}=$ significance level of $1 \%$, respectively $5 \%$

As the growth opportunities for a company become evident, lenders are more interested in crediting it. As a result, the ratio of debt to equity increases as a positive evolution of growth opportunities is registered. According to the results illustrated in Table 5, the 1 percentage point increase in the indicator that quantifies the growth opportunities leads to the increase in leverage by 0.33 percentage points.

As far as the volatility coefficient is concerned, it is negatively correlated with the leverage. An increase in $\beta$ coefficient of 1 percentage point results in a decrease of the leverage by 0.73 percentage points. Basically, the more a company perceives as risky, the lower the ratio debt to equity. This can be explained by the reluctance of creditors to lend to companies that are considered riskier. According to the results obtained, it is observed that the impact of the risk associated with the share on the leverage is the highest. 
In the case of companies listed on the BVB main market, the increase in the proportion of fixed assets in total value of assets determines the decrease of the leverage, in line with the results obtained in the specialized literature for the developing countries. The 1 percentage point increase in asset tangibility causes leverage to decrease by 0.39 percentage points. According to Serghiescu and Vaidean (2014), the insufficiently developed legislative framework governing bankruptcy of companies may cancel the advantage of holding collateralized assets. In addition, in the context of insolvency law, creditors are able to execute the collateral more heavily, and it is a priority to restore the company and the necessary conditions for generating resources for paying debts.

Profitability, current liquidity, growth opportunities, corporate volatility and asset tangibility together account for about $18 \%$ of the capital structure.

The obtained results validate some of the existing theories in the field of capital structure, being synthesized from this point of view on Table 6.

Table 6. Validation of theories in the field of capital structure

\begin{tabular}{cccc}
\hline Variable & $\begin{array}{c}\text { Relation with capital } \\
\text { structure }\end{array}$ & Theory & Validation \\
\hline Profitability & - & Pecking Order Theory & Yes \\
& - & Trade-off Theory (supposes the existence of a & positive correlation) \\
\hline Liquidity & + & Pecking Order Theory & Yes \\
\hline $\begin{array}{c}\text { Golatility coefficient of } \\
\text { unlevered firm stocks } \\
\left(\beta_{U}\right)\end{array}$ & - & Market timing theory & No \\
\hline Tangibility & - & Trade-off Theory & No \\
\hline
\end{tabular}

According to the pecking order theory, to the extent that companies are profitable, they prefer, first of all, the use of reinvested profits. In the case of companies listed on the BVB main market, the increase in profitability is associated with a decrease in the ratio debts to equity.

The inverse relationship between the evolution of profitability and leverage, corroborated with the conclusions on the influence of firm liquidity, confirms the theory developed by Myers (1984). Profitable companies with a high level of liquidity will borrow less, preferring funding from internal resources. These results have been confirmed for the listed companies in Romania and the previous studies.

According to the trade-off theory, rising companies should be less indebted (Myers, 2003) and use preponderant stock financing. For the companies in the sample, the increase in the market value of the equity in relation to the book value determines the increase in the leverage, respectively the increase of the debts in relation to the equity. Thus, in the case of the companies studied, the existence of growth opportunities causes firms to become more indebted. Therefore, the relationship between leverage and the indicator that quantifies the existence of growth opportunities does not validate the trade-off theory for listed companies in Romania.

The volatility coefficient of the stock shows the level of risk associated with it compared to the overall market portfolios (a higher volatility coefficient indicates a higher risk). If a company's shares are perceived as riskier, investors are not interested in a possible investment and the price of the share decreases as a result of falling demand. When stocks are quoted at high prices, their associated risk being perceived as being low, companies may decide to issue new shares in order to benefit from the favourable stock market.

Also, according to trade-off theory, companies with a risk above average should be less indebted (Myers, 2003), which implies an inverse relationship between volatility coefficient and leverage. Therefore, the negative relationship between the volatility coefficient and leverage ratio confirms for the analysed companies the validity of the trade-off theory but not of the market timing theory.

According to trade-off theory, companies with high values of intangible assets should be less indebted (Myers, 2003). In the case of the companies analysed, the sign of dependence between asset tangibility and leverage shows that the increase in the value of tangible assets as a percentage of total assets - and implicitly the reduction in the share of intangible assets - determines a decrease in the ratio of debt to equity.

Therefore, according to the conclusions of this analysis, in line with the results highlighted in the literature for developing countries, less indebted firms have a smaller percentage of intangible assets. This conclusion formulated for the listed companies on the BVB main market is contrary to the trade-off theory. 


\section{Conclusions}

The aim at this study is highlighting the influence of the main factors identified in the literature on the capital structure of listed companies on the BVB's main market, based on the financial statements publicly available in the period 2007-2017.

According to the results obtained, the capital structure of the companies in the sample is positively correlated with the existence of growth opportunities and negatively with the profitability, liquidity, asset tangibility and volatility coefficient.

The firm size variable isn't a significant factor of the capital structure for listed companies on the BVB's main market. A possible explanation for this result could be provided by the degree of homogeneity of the companies in the sample, being companies with access to finance on the capital market, listed in the same category and with the same transparency obligations.

In addition to highlighting factors impacting on the capital structure, this analysis has also contributed to testing the validity of some of the theories established in the literature in the field of financing decision making. Thus, for the companies in the sample, the validity of the pecking order theory and trade-off theory was confirmed based on the results obtained for some of the influencing factors analysed. Regarding the trade-off theory, it was analysed through four factors, namely profitability, the existence of growth opportunities, the stock volatility coefficient and the tangibility, the results obtained confirming the validity of the theory for listed companies in Romania only from the perspective of the risk associated with the shares.

\section{References}

1. Antoniou, A. - Guney, Y. - Paudyal, K. (2008): The Determinants of Capital Structure: Capital Market-Oriented Versus Bank-Oriented Institutions. Journal of Financial and Quantitative Analysis, 43(1): 59-92.

2. Baker, M. - Wurgler, J. (2002): Market Timing and Capital Structure. The Journal of Finance, 57(1): 1-32.

3. Balakrishnan, S. - Fox, I. (1993): Asset specificity, firm heterogeneity and capital structure. Strategic Management Journal, $14(1):$ 3-16.

4. Bradley, M. - Jarrell, G.A. - Kim, E.H. (1984): On the Existence of an Optimal Capital Structure: Theory and Evidence. The Journal of Finance, 39(3): 857-878.

5. Brealey, R.A. - Myers, S.C. (1984): Principles of Corporate Finance. 2nd Edition, New York: McGraw-Hill.

6. Brendea, G. (2014): Financing Behavior of Romanian Listed Firms in Adjusting to the Target Capital Structure, Czech Journal of Economics and Finance, 64(4): 312-329.

7. Chang, X. - Dasgupta, S. (2009): Target behavior and financing: how conclusive is the evidence? Journal of Finance, 64: 1767-1796.

8. De Haas, R. - Peeters, M. (2006): The dynamic adjustment towards target capital structures of firms in transition economies. Economics of Transition, 14(1): 133-169.

9. De Jong, A. - Kabir, R. - Nguyen, T.T. (2008): Capital Structure around the World: The Roles of Firm- and Country-Specific Determinants. Journal of Banking and Finance, 32(9): 1954-1969.

10. De Miguel, A. P. (2001): Determinants of capital structure: new evidence from Spanish panel data. Journal of Corporate Finance, 7: 77 99.

11. Dhaliwal, D. - Krull, L. - Li, O. Z. (2007): Did the 2003 Tax Act reduce the cost of equity capital? Journal of Accounting and Economics, 43(1): 121-150.

12. Donaldson, G. (1961): Corporate Debt Capacity: A study of Corporate Debt Policy and the Determination of Corporate Debt Capacity. Boston. Division of Research, Harvard Graduate School of Business Administration.

13. Dragota, I. M. - Dragota, V. - Obreja Brasoveanu, L. - Semenescu A. (2008): Capital Structure Determinants: A Sectorial Analysis for the Romanian Listed Companies. Economic Computation and Economic Cybernetics Studies and Research, 42(1-2): 155-172.

14. Fama, E. F. - French, K.R. (2002): Testing Trade-Off and Pecking Order Predictions about Dividends and Debt. The Review of Financial Studies, 15(1): 1-33.

15. Flannery, M.J. - Rangan, K.P. (2006): Partial adjustment and target capital structures. Journal of Financial Economics, 79: 469-506.

16. Frank, M.Z. - Goyal, V.K. (2003): Testing the pecking order theory of capital structure. Journal of Financial Economics, 67: 217-248.

17. Jensen, M. C. - Meckling, W. H. (1976): Theory of the firm: Managerial behaviour, agency costs and ownership structure. Journal of Financial Economics, 3(4): 305 -360.

18. Mao, C. (2003): Interaction of Debt Agency Problems and Optimal Capital Structure: Theory and Evidence. Journal of Financial and Quantitative Analysis, 38(02): 399-423.

19. Mokhova, N. - Zinecker, M. (2014): Macroeconomic factors and corporate capital structure. Procedia - Social and Behavioral Sciences, 110: $530-540$.

20. Myers, S. C. (2001): Capital Structure. The Journal of Economic Perspectives, 15(2): 81-102.

21. Nenu, E.A. - Vintila, G. - Gherghina, S.C. (2018): The Impact of Capital Structure on Risk and Firm Performance: Empirical Evidence for the Bucharest Stock Exchange Listed Companies. International Journal of Financial Studies, 6(2): 41.

22. Obreja Brasoveanu, L. - Ciobanu, A. - Brasoveanu, I. (2008): Cost of Capital Considerations. Theoretical and Applied Economics, Supplement: 45-49.

23. Rajan, R.G. - Zingales, L. (1995): What Do We Know about Capital Structure? Some Evidence from International Data. The Journal of Finance, 50(5): 1421-1460.

24. Ross, S.A. (1977): The Determination of Financial Structure: The Incentive-Signalling Approach. The Bell Journal of Economics, 8(1): 23-40.

25. Serghiescu, L. - Vaidean, V. L. (2014): Determinant factors of the capital structure of a firm - an empirical analysis. Procedia Economics and Finance, 15: 1447-1457.

26. Shyam-Sunder, L. -Myers, S. C. (1999): Testing static tradeoff against pecking order models of capital structure. Journal of financial economics, 51(2): 219-244.

27. Sumedrea, S. (2015): How the Companies did Structure their Capital to Surpass Crises? Procedia Economics and Finance, 27: 22-28.

28. Titman, S. - Wessels, R. (1988): The Determinants of Capital Structure Choice. The Journal of Finance, 43(1): 1-19. 
29. Taga, L.A. - Ilie, V. (2017): Capital structure on Romanian listed companies - a post crisis insight. Revista Economica, 69(3): 123-132.

30. Taga, L.A. - Stanica, F.A. (2016a): Capital structure: profitability, tangibility and size of the company. Theoretical and Applied Economics, Special Issue: $104-111$.

31. Taga, L.A. - Stanica, F.A. (2016b): Capital structure: An overview for Romanian listed companies on reputation, size and profitability. SGEM2016 Conference Proceedings, Book 5 Vol. 3: 63-70, Albena, Bulgaria.

32. Vatavu, S. (2015): The impact of capital structure on financial performance in Romanian listed companies. Procedia Economics and Finance, 32: 1314-1322.

33. Vintilă, G. (2006): Gestiunea financiară a întreprinderii. 6th Edition, EDP: Bucharest. 